Tropical Journal of Pharmaceutical Research June 2021; 20 (6): 1119-1124

ISSN: $1596-5996$ (print); 1596-9827 (electronic)

(C) Pharmacotherapy Group, Faculty of Pharmacy, University of Benin, Benin City, 300001 Nigeria.

Available online at http://www.tjpr.org

Original Research Article

http://dx.doi.org/10.4314/tjpr.v20i6.3

\title{
MiR-21 inhibits the proliferation of childhood cholesteatoma glioma cells by negatively regulating the expressions of PTEN and PDCD4
}

\author{
Xiaozhen Chen ${ }^{1}$, Fei Xiao ${ }^{2}$, Shanwu Dong ${ }^{1}$, Yongli Chen ${ }^{1}$, Jiwu Wang ${ }^{3 *}$ \\ ${ }^{1}$ Department of Pediatrics, ${ }^{2}$ Department of Abdominal Surgery, ${ }^{3}$ Department of Cardiothoracic Surgery, Wuhan Fourth Hospital, \\ Wuhan 430000, Hubei Province, China
}

*For correspondence: Email: qcpp59@163.com

Sent for review: 18 March 2021

Revised accepted: 30 May 2021

\begin{abstract}
Purpose: To determine the effect of MiR-21 on the proliferation of glioma cells in children with cholesteatoma, and the pathway involved.

Methods: Cholesteatoma tissues from children with cholesteatoma in Otology Department of our hospital were isolated, extracted and cultured in serum-free medium of keratinocytes. The experiment comprised three groups: negative control group, blank control group and miR-21 inhibition group. Cell cycle and cell proliferation were analyzed. $m R N A$ and protein expressions of phosphatase tension homologue (PTEN) and programmed cell death factor-4 (PDCD4) were determined.

Results: The proliferation of CK cells in miR-21 group was significantly lower than that in negative control and blank control groups ( $p<0.05$ ). The proportion of CK cells at G0/G1 phase in miR-21 inhibition group was significantly higher than those in negative control and blank control groups $(p<$ 0.05). The protein and mRNA expression levels of PTEN and PDCD4 in CK in miR-21 group were significantly higher than those in negative control and blank control groups $(p<0.05)$.

Conclusion: Inhibition of miR-21 slows down cell proliferation to some extent, and induces apoptosis of cholesteatoma cells by inducing cell cycle arrest at G0/G1 phase via a mechanism linked to the negative regulation of expressions of PTEN and PDCD4. Thus, MiR-21 can be used as potential target for the drug of treatment of children with cholesteatoma.
\end{abstract}

Keywords: MiR-21, PTEN, PDCD4, Apoptosis, Cholesteatoma, Glioma, Cell proliferation

\begin{abstract}
This is an Open Access article that uses a fund-ing model which does not charge readers or their institutions for access and distributed under the terms of the Creative Commons Attribution License (http://creativecommons.org/licenses/by/4.0) and the Budapest Open Access Initiative (http://www.budapestopenaccessinitiative.org/read), which permit unrestricted use, distribution, and reproduction in any medium, provided the original work is properly credited.

Tropical Journal of Pharmaceutical Research is indexed by Science Citation Index (SciSearch), Scopus, International Pharmaceutical Abstract, Chemical Abstracts, Embase, Index Copernicus, EBSCO, African Index Medicus, JournalSeek, Journal Citation Reports/Science Edition, Directory of Open Access Journals (DOAJ), African Journal Online, Bioline International, Open-J-Gate and Pharmacy Abstracts
\end{abstract}

\section{INTRODUCTION}

Cholesteatoma of the middle ear, a relatively common and frequently occurring disease, is an abnormal accumulation of keratin-producing squamous epithelium in the middle tympanum, superior tympanum, and mastoid process or rocky apex [1]. The progressive destruction of the hearing structure of the middle ear and the adjacent skull by cholesteatoma not only damages the hearing of the patient, it may also lead to serious complications such as facial neuropathy, facial paralysis, vestibular lesion vertigo, intracranial infection and brain abscess [2]. 
Cholesteatoma is a benign recurrent lesion with aggressive, migratory, destructive and highly proliferative tumor-like biological behaviors [3]. Cholesteatoma in children has a rapid growth rate and a wide range of lesions, and it spreads easily, with significantly higher postoperative recurrence than cholesteatoma in adults [4]. MicroRNAs (miRNAs) are important regulators of translation, and they are closely related to the etiology of tumors and abnormal hyperplastic diseases [5]. It has been reported that MiR-21, a relatively extensive type of miRNA in human cells or tissues, is significantly overexpressed in inflammatory pathological conditions such as colitis, osteoarthritis, psoriasis, allergic respiratory inflammation and ventricular hypertrophy [6].

It has been found that miRNA-21 is significantly overexpressed in cholesteatoma tissue, and may be involved in the etiology of cholesteatoma cells [7]. In this study, cholesteatoma cells were used to study the effect of miR-21 on the proliferation of glial cells in children cholesteatoma, as well as the related mechanisms.

\section{EXPERIMENTAL}

\section{Cell lines}

Cholesteatoma keratinocytes were cultured in keratinocyte serum-free medium after isolation and extraction from children with cholesteatoma in our hospital. Experimental cells in exponential growth stage were cultured at $37{ }^{\circ} \mathrm{C}$ and $5 \%$ $\mathrm{CO}_{2}$.

\section{Reagents}

The reagents used were crystal violet staining solution (Shanghai Jizhi Biochemical Technology Co. Ltd); EDU cell proliferation detection kit (Guangzhou Ruibo Biotechnology Co. Ltd); cell cycle kit (Hangzhou Lianke Biotechnology Co. Ltd); in situ apoptosis (TUNEL) detection kit (Shanghai Jizhi Biochemical Technology Co. Ltd); mouse anti-human PTEN monoclonal antibody (Beijing Norblad Technology Co. Ltd), and mouse anti-human PDCD4 monoclonal antibody (Beijing Norblad Technology Co. Ltd).

\section{Equipment}

Fluorescence microscope was provided by Nanjing Baden Medical Co. Ltd. Flow cytometer was product of Shanghai Ranzhe Instrument \& Equipment Co. Ltd. Carbon dioxide incubator was obtained from Shenzhen Reward Life Technology Co. Ltd. Ultra-low temperature refrigerator was purchased from Wuxi Leifsi
Biological Experimental Equipment Co., while high speed table top centrifuge was obtained from Beijing Ganming Gene Technology Co. Ltd.

\section{Cell transfection}

The viral vector, pWPXLd, was used as the transfer plasmid vector carrying the target gene. The gene sequence of the inhibitor miRNA-21 was TCAACATCALRGTGAAGCT'A, while the gene sequence of the negative control was TTCTCCGAACGTGTCACGT. The experimental groups were negative control group, blank control group and miR-21 inhibition group. CK was inoculated in 6-well plates. The viruses were taken out from a $-80{ }^{\circ} \mathrm{C}$ refrigerator and suspended in a water bath. In the miR-21 inhibition group, $200 \mu \mathrm{L}$ of miR-21 inhibitor lentivirus was added to each well, and in the negative miR-21 group, $200 \mu \mathrm{L}$ of control miR-21 lentivirus was added to each well. In the blank control group, $200 \mu \mathrm{L}$ of PBS was added to each well. Then, $5 \mu \mathrm{L}$ of polybrene was added to each well. The medium in each well was replaced every $24 \mathrm{~h}$.

\section{Cell cycle analysis}

Cells in each group were digested and counted. The cells were washed once with PBS. After centrifugation, the cell density was adjusted to $1 \times 10^{6}$ cells $/ \mathrm{mL}$, and $1 \mathrm{~mL}$ single-cell suspension was taken. The supernatant was removed by centrifugation and fixed with $500 \mu \mathrm{L}$ cold ethanol at a concentration of $70 \%$ in cells, and stored at $4^{\circ} \mathrm{C}$. The fixation solution was washed off with PBS before staining. Then, $100 \mu \mathrm{L}$ RNASeA was added in $37^{\circ} \mathrm{C}$ water bath for $30 \mathrm{~min}$, followed by staining with $200 \mu \mathrm{L} \mathrm{PI}$ in the dark at $4{ }^{\circ} \mathrm{C}$ for 30 $\mathrm{min}$. The red fluorescence was recorded at the excitation wavelength of $488 \mathrm{~nm}$.

\section{Evaluation of cell proliferation}

The cells at logarithmic growth phase were seeded into 96-well plates at a density of $4 \times 10^{5}$ cells per well. Then, $100 \mu \mathrm{L}$ of $50 \mu \mathrm{M}$ EDU medium was added to each well and incubated for $2 \mathrm{~h}$, followed by washing of the cells with PBS, addition of $100 \mu \mathrm{L}$ of cell fixation solution to each well, and incubation for $30 \mathrm{~min}$ at room temperature. Then, $2 \mathrm{mg} / \mathrm{mL}$ glycine was added to each well and incubated for $5 \mathrm{~min}$ on decolorizing shaker, followed by removal of the glycine solution. Each well was washed with 100 $\mu \mathrm{L}$ PBS for $5 \mathrm{~min}$, followed by addition of penetrant, and incubation on a decolorizing shaker for $10 \mathrm{~min}$. After rinsing once with PBS for $5 \mathrm{~min}, 100 \mu \mathrm{L}$ of Apollo dyeing reaction solution was added to each well and incubated for $30 \mathrm{~min}$ 
on a decolorizing shaker in the dark at room temperature. Then, each well was rinsed twice with $100 \mu \mathrm{L}$ of methanol. After washing the mixture once with PBS, $100 \mu \mathrm{L}$ of Hoechst 33342 reaction solution was put into each well, and incubated on a decolorizing shaker in a dark place at room temperature for $30 \mathrm{~min}$. Finally, $100 \mu \mathrm{L}$ of PBS was used to rinse each well twice, followed by examination under a fluorescence microscope.

\section{Determination of cell apoptosis}

The CK in each group was digested and the cells were washed twice with PBS, followed by suspension of the cells in $500 \mu \mathrm{L}$ of binding buffer. After mixing, $5 \mu \mathrm{L}$ of Annexin V-FITC and $5 \mu \mathrm{L}$ of propidium iodide were serially added. The reaction was allowed to take place for 15 min at room temperature in the dark, followed by flow cytometric analysis. CellQuest software analysis was used to obtain the percentage of early apoptosis of cells.

\section{Determination of expressions of miRNA in PTEN and PDCD4}

When the adherent cell lines grew to $80 \%$ fusion in the 6 -well plate, $1 \mathrm{~mL}$ of lysing solution was added to the cells and placed at room temperature for $5 \mathrm{~min}$. Then, $0.2 \mathrm{~mL}$ trichloromethane was added and centrifuged at room temperature. The upper aqueous phase was transferred to a new centrifuge tube without RNAase, and $1.5 \%$ volume of $100 \%$ ethanol was added to the centrifuge tube, followed by centrifugation at room temperature. Then, $700 \mu \mathrm{L}$ of bleaching solution WB was added to the centrifuge tube, followed by centrifugation for 15 sec, addition of $500 \mu \mathrm{L}$ of rinsing solution, and centrifugation at room temperature. Thereafter, a silica gel film was dried on an empty column at $10,000 \mathrm{rpm}$ for $2 \mathrm{~min}$. The centrifuge tube content was transferred to a new RNA-free centrifuge tube containing $50 \mu \mathrm{L}$ of RNAase-free water, and left to stand at room temperature prior to centrifugation. Then, $2 \mu \mathrm{l}$ of RNA solution was taken from each sample, and the RNA concentration was measured in terms of A260/A280 ratio using a micro-UV spectrophotometer. Reverse transcription real time quantitative PCR (RT-PCR) was used to determine mRNA expressions, and the $2-\triangle \triangle C T$ method was used to analyze the relative mRNA expression levels.

\section{Western blotting}

The CK of each group was digested and centrifuged, and the protein concentration of the supernatant was determined. A quarter volume of $5 \times$ Sodium dodecyl sulfate (SDS) loading buffer was added to the protein extract, which was fully mixed and boiled for $5 \mathrm{~min}$ for denaturation. The protein was subjected to SDSpolyacrylamide gel electrophoresis and transferred to PVDF (poly(1,1-difluoroethylene)) membrane which was blocked by incubation with TBST blocking solution containing $5 \%$ skimmed milk overnight. The milk was washed off with TBST, followed by incubation of the PVDF membrane with primary antibodies overnight. Thereafter, the membrane was rinsed thrice with TBST, followed by incubation with HRP-linked secondary antibody at room temperature for $2 \mathrm{~h}$. The membrane was subjected to enhanced chemiluminescence (ECL) analysis, and the relative expressions were determined using $x$-ray film. The film was naturally air-dried at room temperature, and the results were scanned and stored.

\section{Statistical analysis}

Measurement data are expressed as mean \pm SD. The data were analyzed with SPSS 20.0 software package. Comparison between two groups was done with $t$-test. Counting data are expressed as percentage, and the comparison between groups was done with $x^{2}$ test. Values of $p<0.05$ were assumed to indicate statistically significant differences.

\section{RESULTS}

\section{CK growth curve}

The CK growth curve of each group showed an increasing trend with time. During 5 - 11 days, the CK cell density in the miR-21 inhibition group was significantly lower than that in the negative control and the blank control groups $(p<0.05)$. These results are shown in Figure 1.

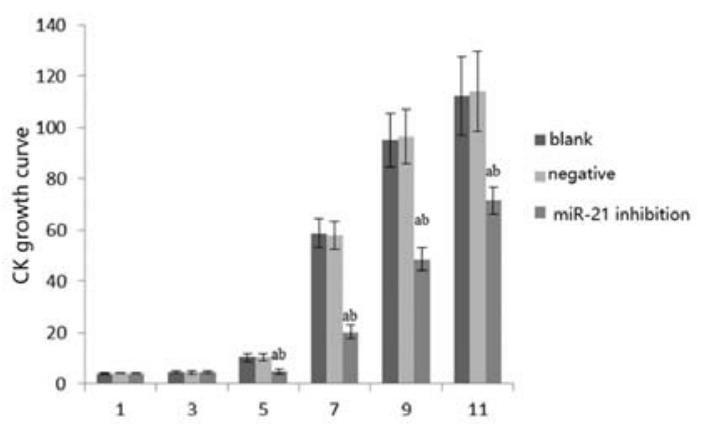

Figure 1: CK growth curve in each group. ${ }^{a} P<0.05$, compared with blank control group; ${ }^{b} p<0.05$, compared with negative control group 


\section{CK cell proliferation}

The $\%$ proliferation of $\mathrm{CK}$ cells in miR-21 inhibition group was significantly lower than those in the negative control and blank control groups $(p<0.05)$. However, there was no significant difference in $\%$ cell proliferation between the negative control group and blank control group $(p>0.05)$. These data are shown in Figure 2.

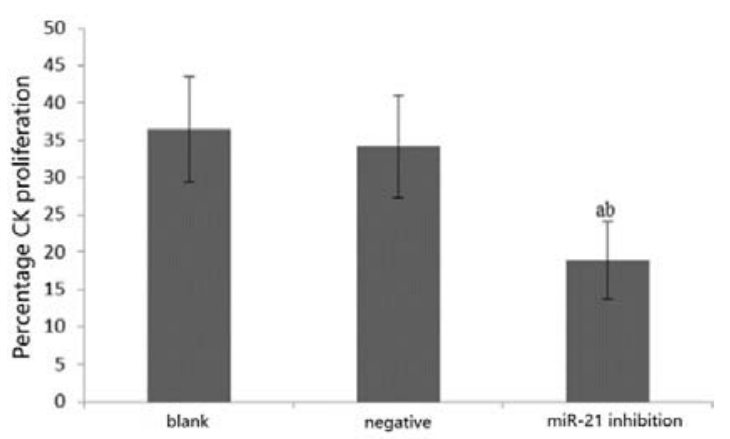

Figure 2: $\mathrm{CK}$ proliferation in each group. ${ }^{\mathrm{a}} P<0.05$, compared with blank control group; ${ }^{b} p<0.05$, compared with negative control group

\section{Cell cycle distribution}

Table I shows that the proportion of CK cells in G0/G1 phase in the miR-21 inhibition group was significantly higher than those in the negative control and the blank control groups, while the proportion of $\mathrm{CK}$ cells in the $\mathrm{S}$ phase was significantly lower than those in the negative control and the blank control groups $(p<0.05)$. There was no statistical significance in the proportion of CK cells in G2/M phase among all groups $(p>0.05)$.

Table 1: CK cell cycle distribution in each group

\begin{tabular}{|c|c|c|c|}
\hline Group & $\begin{array}{c}\mathbf{G}_{0} / \mathbf{G}_{1} \text { phase } \\
(\%)\end{array}$ & $\begin{array}{c}\text { S phase } \\
(\%)\end{array}$ & $\begin{array}{c}\mathbf{G}_{2} / \mathbf{M} \\
\text { phase (\%) }\end{array}$ \\
\hline Blank & $42.85 \pm 1.52$ & $39.85 \pm 1.98$ & $17.56 \pm 1.25$ \\
\hline Negative & $49.81 \pm 3.58^{a}$ & $\begin{array}{c}33.85 \pm 1.45 \\
a\end{array}$ & $16.34 \pm 1.02$ \\
\hline $\begin{array}{l}\text { miR-21 } \\
\text { inhibition }\end{array}$ & $65.38 \pm 4.28^{\mathrm{ab}}$ & $\underset{\mathrm{ab}}{16.32 \pm 1.67}$ & $18.30 \pm 4.71$ \\
\hline
\end{tabular}

\section{Cell apoptosis}

As shown in Figure 3, the \% apoptosis of CK cells in miR-21 inhibition group was significantly higher than the corresponding levels in negative control and blank control groups $(p<0.05)$. However, there was no significant difference in $\%$ apoptosis between the negative control group and blank control group $(p>00.05)$.

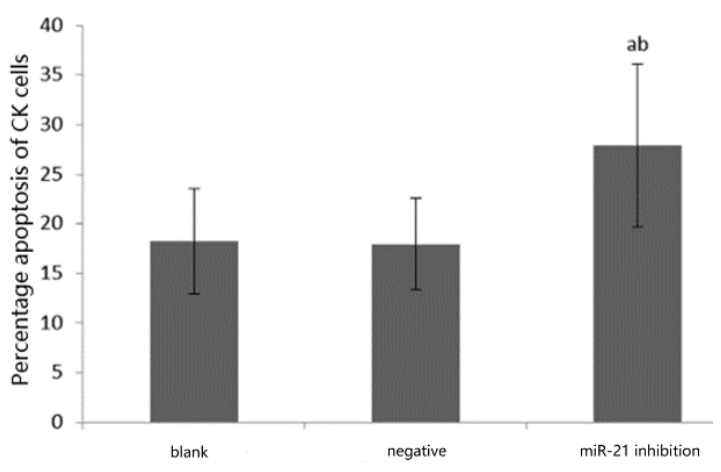

Figure 3: Apoptosis of CK cells in each group. ${ }^{a} P<$ 0.05 , compared with blank control group; ${ }^{b} p<0.05$, compared with negative control group

\section{mRNA and protein expressions of PTEN and PDCD4}

The mRNA and protein expressions expression levels of PTEN and PDCD4 in CK in miR-21 inhibition group were significantly higher than those in the negative control and blank control groups $(p<0.05)$. However, there were no significant differences in the mRNA and protein expression levels of PTEN and PDCD4 in CK between the negative control and blank control groups $(p>0.05)$. These results are presented in Table 2 and Figure 5.

Table 2: mRNA and protein expressions of PTEN and PDCD4 in CK of each group

\begin{tabular}{lcc}
\hline Group & PTEN & PDCD4 \\
\hline Blank & $1.02 \pm 0.02$ & $1.03 \pm 0.02$ \\
Negative & $1.03 \pm 0.01$ & $1.01 \pm 0.02$ \\
miR-21 inhibition & $2.84 \pm 0.16^{\mathrm{ab}}$ & $1.89 \pm 0.08^{\mathrm{ab}}$ \\
\hline${ }^{\mathrm{a} P}<0.05$, compared with blank control group; ${ }^{\mathrm{b}} p<$ \\
0.05, compared with negative control group
\end{tabular}

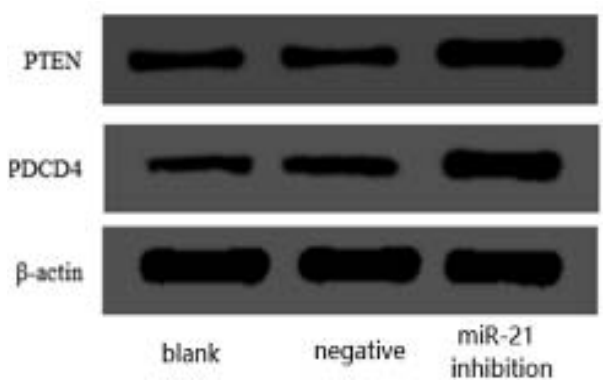

Figure 4: Protein expressions of PTEN and PDCD4 in CK

\section{DISCUSSION}

Cholesteatoma of the middle ear presents a cystic structure with a lamellar squamous epithelium composed of keratinocytes. The 
keratinocytes in the epithelium of cholesteatoma are characterized by excessive proliferation. The continuous growth of the epithelium can cause the inner layer cells to undergo necrosis and fall off. Thus, the cholesteatoma sac is always filled with exfoliated epithelium, keratinized substances and cholesterol crystals [8]. Cholesteatoma is characterized by abnormal proliferation and invasion. However, studies on cholesteatoma are limited.

Abnormal cell proliferation is a characteristic feature of malignant tumors. Previous studies have shown that many oncogenes and tumor suppressor genes related to cell cycle, invasion and apoptosis may be regulated by miRNAs [9]. As one of the earliest miRNAs discovered by human beings, miR-21 is also one of the more commonly overexpressed miRNAs in malignant tumor tissues. It participates in cell proliferation and apoptosis by targeting and regulating tumor suppressor genes and oncogenes. Zhang et al. reported that overexpression of $\mathrm{miR}-21$ promotes proliferation, migration and invasion of hepatoma cells [10]. Ding et al found that overexpression of miR-21 induced proliferation and migration of colon cancer tissue cells [11]. In this study, the growth of CK in each group showed an increasing trend over time. In 5 - 11 days, the density of CK cells in the miR-21 inhibition group was significantly lower than the corresponding densities in the negative control and the blank control groups. The percentage proliferation of CK cells in miR-21 inhibition group was significantly lower than those in the negative control and blank control groups. These results indicate that inhibition of miR-21 slows down cell proliferation, which is similar to the results of $\mathrm{Fu}$ et al [12].

In a study by $\mathrm{Fu}$ et al on antisense nucleotide knockdown of abnormal expression of miR-21 in glioblastoma, it was found that miR-21 induced apoptosis of tumor cells by activating the caspase cascade in glioblastoma [13]. Li et al showed that inhibition of miR-21 significantly promoted apoptosis of bile duct tumor cells [14]. It was further confirmed that miR-21 regulated cell apoptosis. In this study, the percentage apoptosis of CK cells in the miR-21 inhibition group was significantly higher than those in the negative control and the blank control groups. The proportion of CK cells in G0/G1 phase in the miR-21 inhibition group was significantly higher than the corresponding values in the negative control and blank control groups, while the proportion of cells in $S$ phase was significantly lower than those in the negative control and the blank control groups. These results suggest that miR-21 inhibition induces apoptosis of cholesteatoma cells by inducing arrest of cholesteatoma cell cycle at the G0/G1 phase. However, the effect of miR-21 inhibition on the glial cells of cholesteatoma, and the mechanism involved, need to be further studied.

Dan et al [15] found that miR-21 plays an important role in the regulation of abnormal tumor proliferation through its target genes PTEN and PDCD4, making it an "oncogene". It is known that PTEN is a tumor suppressor gene that induces cell cycle arrest and initiates programmed cell death, while PDCD4, a tumor suppressor gene related to the cell cycle, inhibits cell proliferation and transformation, and promotes cell apoptosis [16-17]. In this study, the mRNA and protein expression levels of PTEN and PDCD4 in CK of miR-21 inhibition group were significantly higher than those in the negative control and blank control groups. These results suggest that miR-21 may be involved in the proliferation, apoptosis and invasion of cholesteatoma keratinocytes due to its targeted regulation of the expressions of PTEN and PDCD4.

\section{CONCLUSION}

Inhibition of miR-21 slows down cell proliferation to a certain extent, and induces apoptosis of cholesteatoma cells by inducing cell cycle arrest at the G0/G1 phase, thereby inhibiting cell invasion. These effects are exerted through negative regulation of the expressions of the target genes, PTEN and PDCD4. Thus, miR-21 may play a role in the management of children suffering cholesteatoma.

\section{DECLARATIONS}

\section{Conflict of interest}

No conflict of interest is associated with this work.

\section{Contribution of authors}

We declare that this work was performed by the authors named in this article and all liabilities pertaining to claims relating to the content of this article will be borne by the authors. Jiwu Wang and Xiaozhen Chen designed the study, supervised the data collection, and analyzed the data. Xiaozhen Chen interpreted the data and prepared the manuscript for publication. Fei Xiao, Shanwu Dong and Yongli Chen supervised the data collection, analyzed the data and reviewed the draft of the manuscript. 


\section{Open Access}

This is an Open Access article that uses a funding model which does not charge readers or their institutions for access and distributed under the terms of the Creative Commons Attribution License (http://creativecommons.org/licenses/by/ 4.0) and the Budapest Open Access Initiative (http://www.budapestopenaccessinitiative.org/rea d), which permit unrestricted use, distribution, and reproduction in any medium, provided the original work is properly credited.

\section{REFERENCES}

1. Yamamoto-Fukuda $T$, Hishikawa $Y$, Shibata $Y$, Kobayashi T, Takahashi H, Koji T. Pathogenesis of middle ear cholesteatoma: a new model of experimentally induced cholesteatoma in Mongolian gerbils. Am J Pathol 2010; 176(6): 2602-2606.

2. Olszewska E, Matulka M, Mroczko B, Pryczynicz A, Kemona A, Szmitkowski M, Mierzwinski J, Pietrewicz T. Diagnostic value of matrix metalloproteinase 9 and tissue inhibitor of matrix metalloproteinases 1 in cholesteatoma. Histol Histopathol 2016; 31(3): 307-315.

3. Zou J, Isomäki A, Hirvonen $T$, Aarnisalo A, Jero J, Pyykkö I. Label-free visualization of cholesteatoma in the mastoid and tympanic membrane using CARS microscopy. J Otol 2016; 11(3): 127-133.

4. Bo $Y$, Yang $Y$, Xiaodong $C$, Xi W, Keyong $T, Y u Z, Y e W$, Kun $L$, Zheng $Y$, Yang $C$, et al. A retrospective study on post-operative hearing of middle ear cholesteatoma patients with labyrinthine fistula. Acta Otolaryngol 2016; 136(1): 8-11.

5. Zhang $X$, Wang $C$, Shan $S$, Liu $X$, Jiang $Z$, Ren $T$. TLR4/ROS/miRNA-21 pathway underlies lipopolysaccharide instructed primary tumor outgrowth in lung cancer patients. Oncotarget 2016; 7(27): 4217242182.

6. Alemar B, Izetti $P$, Gregório C, Macedo GS, Castro MA, Osvaldt AB, Matte U, Ashton-Prolla P. miRNA-21 and miRNA-34a Are Potential Minimally Invasive Biomarkers for the Diagnosis of Pancreatic Ductal Adenocarcinoma. Pancreas 2016; 45(1): 84-92.
7. Wu Y, Zhang J, Hong $Y$, Wang $X$. Effects of Kanglaite Injection on Serum miRNA-21 in Patients with Advanced Lung Cancer. Med Sci Monit 2018; 24: 2901-2906.

8. Shi Z, Han J, Qin J, Zhang Y. Clinical application of diffusion-weighted imaging and dynamic contrastenhanced MRI in assessing the clinical curative effect of early ankylosing spondylitis. Medicine (Baltimore) 2019; 98(20): e15227.

9. Cao CL, Niu HJ, Kang SP, Cong CL, Kang SR. miRNA21 sensitizes gastrointestinal stromal tumors (GISTS) cells to Imatinib via targeting B-cell lymphoma 2 (Bcl-2). Eur Rev Med Pharmacol Sci 2016; 20(17): 3574-1581.

10. Zhang $H H$, Wang $X N$, He $X$. Interaction between $H B x$ and microRNA-21 in hepatocellular carcinoma and its mechanism. Med Innov Chin 2017; 014(036): 9-12.

11. Xu Z, Zhang $Y, X u M$, Zheng $X$, Lin M, Pan J, Ye C, Deng $Y$, Jiang $C, \operatorname{Lin} Y, \operatorname{Lu} X$, Chi $P$. Demethylation and Overexpression of CSF2 are Involved in Immune Response, Chemotherapy Resistance, and Poor Prognosis in Colorectal Cancer. Onco Targets Ther 2019; 12: 11255-11269.

12. Fu D, Dong J, Li P, Tang C, Cheng W, Xu Z, Zhou W, Ge J, Xia C, Zhang Z. MiRNA-21 has effects to protect kidney injury induced by sepsis. Biomed Pharmacother 2017; 94: 1138-1144.

13. Basu B, Ghosh MK. Extracellular Vesicles in Glioma: From Diagnosis to Therapy. Bioessays 2019; 41(7): e1800245.

14. Li H H, Liu J S. Research progress of microRNA-21 in the development and progression of bile duct carcinoma. Chin J Digestive Surg 2016; (7): 751-754.

15. Dan J, Wang J, Wang $Y$, Zhu $M$, Yang $X$, Peng Z, Jiang $H$, Chen L. LncRNA-MEG3 inhibits proliferation and metastasis by regulating miRNA-21 in gastric cancer. Biomed Pharmacother 2018; 99: 931-938.

16. Feng T, Liu Y, Li C, Li Z, Cai H. DEK proto-oncogene is highly expressed in astrocytic tumors and regulates glioblastoma cell proliferation and apoptosis. Tumour Biol 2017; 39(7): 1-7.

17. Hu Y, Wei M, Niu Q, Ma R, Li Y, Wang X, Feng G, Li S, Pang $L$. Grape seed proanthocyanidin extract alleviates arsenic-induced lung damage through NF-KB signaling. Exp Biol Med (Maywood) 2019; 244(3): 213-226. 